\title{
ALGORITHM FOR CARRYING OUT A PROCEDURE FOR VERIFICATION OF A SPECTROPHOTOMETRIC METHOD FOR ANALYSIS OF SOLID-DOSED DOSAGE FORMS ACCORDING TO THE REQUIREMENTS OF SPHU 2.0
}

\author{
(C) N. Bevz, V. Georgiyants, O. Gryzodub
}

\begin{abstract}
Мета. Збільшення на фармачевтичному ринку України асортименту лікарських засобів призводить до більш жорстких вимог до їх якості. Згідно вимог міжнародних стандартів ISO, ICH, GMP, діючого законодавства України та Державної фармакопеї Украӥни, препарати-генерики мають бути еквівалентними, а методики аналізу, що застосовуються для проведення контролю якості, валідовані або верифіковані.
\end{abstract}

Одним з доступних методів аналізу, щзо можна застосовувати як в умовах аптеки, так $і$ в лабораторіях контролю якості на підприємствах і в незалежних контрольно-аналітичних лабораторіях є абсорбційна спектрофотометрія в ультрафіолетовій та видимій областях.

Матеріали та методи. Метод абсорбиійної спектрофотометрії в ультрафіолетовій та видимій областях використовується для кількісної оцінки активних фармацевтичних інгредієнтів в таблетованих готових лікарських формах при кількісному визначенні і при проведені фармако-технологічних випробувань, таких як «Розчинення» $i$ «Однорідність вмісту».

Результати. Для використання методу абсорбиійної спектрофотометрії для кількісної оиінки активних фармацевтичних інгредієнтів в готових лікарських засобах необхідно провести верифікацію запропонованих методик і вивчити такі валідаційні характеристики, як специффічність, лінійність, правильність і преиизійність.

При иьому невизначеність результатів аналізу $\Delta_{A s}$, виражена як односторонній довірчий інтервал для ймовірності $95 \%$, і яка складається з невизначеності пробопідготовки $\left(\Delta_{\text {Sp }}\right)$ i невизначеності кінцевої аналітичної операції $\left(\Delta_{F A O}\right)$, не має перевищувати максимально допустиму повну невизначеність аналізу $\left(\max \Delta_{A s}\right)$.

Висновки. Вивчено підходи Державної фармакопеї Украӥни до методик визначення кількісного вмісту діючих речовин в таблетках при випробуваннях «Кількісне визначення», «Розчинення», "Однорідність. Запропоновано процедуру верифікачії методик кількісного визначення готових лікарських засобів методом абсорбиійної спектрофотометрії в ультрафіолетовій та видимій областях згідно з вимогами 2-го видання Державної Фармакопеї України

Ключові слова: валідація, верифікація, абсорбиійна спектрофотометрія, готові лікарські засоби, таблетки, статистичний аналіз

Copyright @ 2019, N. Bevz, V. Georgiyants, O. Gryzodub.

This is an open access article under the CC BY license (http://creativecommons.org/licenses/by/4.0).

\section{Introduction}

The pharmaceutical industry of Ukraine occupies one of the leading places in the world and is constantly evolving. Domestic manufacturers, choosing a course for import substitution, increase production volumes and carry out modernization of capacities in accordance with GMP standards. At the same time, requirements for the quality of products produced by enterprises are increasing. One of the conditions put forward for pharmaceutical products is the satisfaction of the needs of consumers according to their purpose and compliance with the requirements established by the legislation.

In Ukraine, the production of pharmaceutical products is carried out by about 117 domestic enterprises, among which are such powerful as Arterium Corporation, JSC "Farmak", PrJSC "Pharmaceutical Firm "Darnitsa", JSC "Research laboratory GNCLS", LLC "Pharmaceutical company "Zdorovye", JSC «Kiev Vitamin Plant», PJSC SIC "Borshchahivskiy CPP”, Group of pharmaceutical companies "Lekhim" etc. [1].
Requirements for quality control of manufactured medicinal products are regulated, provided and controlled by the State Pharmacopoeia of Ukraine (SPHU). In 2001, the first edition of the State Pharmacopoeia of Ukraine, harmonized with the European Pharmacopoeia, and quality standards included general articles and monographs on the substance [2]. With the release in 2015 of the 2nd edition of the State Pharmacopoeia, the number of monographs on finished medicines significantly increased, attention is paid to monographs on medicinal plant raw materials, veterinary and homeopathic preparations, serums, vaccines, extemporal formulations, etc.

Among the finished drugs, about $40 \%$ of the production is made up of solid dosage forms, the manufacture of which, due to the convenience of dosing and application, increases annually by $10-15 \%$. The growth of the range of solid pharmaceutical forms of industrial production requires the development and improvement of existing quality control methods, both for new products and for those that have long been produced by domestic 
enterprises. All this causes the State Enterprise Ukrainian Scientific Pharmacopoeial Center for Quality of Medicines" to introduce new monographs on finished drug products.

2. Formulation of the problem in a general way, the relevance of the theme and its connection with important scientific and practical issues

Today, the State Pharmacopoeia of Ukraine, when creating monographs for medicinal products, relies on the experience of leading pharmacologists of the world and its national peculiarities. Pharmacopoeial methods of quality control and analytical techniques that are developed should be subject to the validation process, which allows them to be used in the future to avoid costly and time-consuming costs in analytical practice $[3,4]$. When developing monographs for finished medicines, when existing pharmacopoeial techniques are used, the study of validation characteristics can be reduced by conducting the verification procedure [5].

3. Analysis of recent studies and publications in which a solution of the problem is described and to which the authors refer

The general monograph of the first edition of SPhU on the dosage form "Tablets" put forward the requirements for the determination of the characteristics of production and testing of the finished drug products [6]. Employees of the State Pharmacopoeia of Ukraine, based on the requirements of the general article "Tablets" and section 2.2.N.2 "Validation of analytical methods and tests", for the production of monographs on finished medicines, the Standard working methodology (SWM) was proposed "The procedure for verification of analytical methods in research laboratories" [7]. The SWM sets out the basic requirements for conducting verification studies and the volume of materials provided in the SPhU as analytical support for monographs that are being reviewed or planned for development.

\section{The field of research considering the general problem, which is described in the article \\ In 2015, the 2nd edition of the State Pharmaco-} poeia of Ukraine came into force, according to which the requirements changed the requirements for both tablet drugs, for example, the section "Quantitative determination", as well as to study some validation characteristics $[4,8]$. Each subsequent edition of the State Pharmacopoeia of Ukraine relies on new requirements for quality control of medicines, offers new methods of analysis and requires compliance with certain metrological parameters. With the introduction of the second edition of SPHU somewhat changed the requirements for the statistical processing of the results of the chemical experiment, which, in turn, led to changes in the study of some validation characteristics [9, 10].

\section{Formulation of goals (tasks) of article}

Improvement of the verification procedure for spectrophotometric methods for quantitative determination of quality control of solid dosage finished medicines in accordance with the requirements of the second edition of the State Pharmacopoeia of Ukraine.

6. Statement of the basic material of the study (methods and objects) with the justification of the results

Verification - providing objective evidence that this element fulfils the specified requirements (ISO / IEC Guide 99: 2007(R2015) [11, 12].

One of the requirements for the verification is the availability of experience in personnel, the ability to perform analysis techniques depending on the equipment used and the object under review.

Thus, before conducting the verification of the pharmacopoeial technique, the following factors must be taken into account [13]:

- a laboratory that reproduces analytical techniques should be equipped with appropriate equipment;

- reagents for the reproducibility of analytical techniques must meet the requirements of the pharmacopoeia, according to which research is conducted;

- laboratory analysts are able to correctly reproduce the pharmacopoeial technique or test using specific analytical equipment;

- in pharmacovigilance control, pharmacopoeial techniques can only be used after confirmation that this medicinal product does not lead to an unacceptable deterioration of the metrological characteristics of the procedure (for example, correctness, linearity, or precision).

The verification procedure must be carried out before the first use of the analytical method of purpose to confirm that the method gives the expected results in a particular laboratory. To substantiate the standardized verification process, we split it into several basic steps.

The preparatory stage of the verification involves the justification of the number of series of medicinal product for testing.

Since 2013, in order to create conditions for the export of domestic medicinal products, the certification of the quality of medicinal products and the conditions of their production for the requirements of good manufacturing practice has been in force in Ukraine and in the world [11]. For the most part, domestic manufacturers of the pharmaceutical industry produce finished drugs with similar active pharmaceutical ingredients (API), in which the composition and content of auxiliary substances tend to be somewhat different, which requires the creation of identical methods of quality control, that is, monographs of the pharmacopoeia. For example, tablets containing the active component of metoprolol tartrate are produced by such companies as JSC "Farmak" and JSC "Kievmedpreparat", verapamil hydrochloride - PrJSC "Pharmaceutical Firm "Darnitsa", JSC "Research laboratory GNCLS", LLC "Pharmaceutical company "Zdorovye", JSC "Pharmex Group", PJSC SIC "Borshchahivskiy CPP”, amlodipine besilat - JSC "Farmak", JSC «Kiev Vitamin Plant», PrJSC "Technolog", PrJSC "Pharmaceutical Firm "Darnitsa", JSC "Kievmedpreparat", LLC "Pharmaceutical company "Zdorovye", PC "Astrapharm", PrJSC "Fitopharm”, LLC "KusumPharm” and so on.

In this case, to justify the number of series of medicinal product proceed as follows. If the pharmaceutical form with the same API is manufactured by 
several companies in the country, it is advisable to conduct the study on samples of one or two series of at least three leading Ukrainian manufacturers or foreign brands manufacturers.

In the case when a medicinal product is manufactured by only one manufacturer, the verification procedure is subjected to at least three series of products. Thus, for example, tablets containing hydrochlorothiazide are only released by PJSC SIC "Borshchahivskiy CPP", propranolol hydrochloride - "Pharmaceutical Company "Zdorovya" JSC.

Thus, justification of the number of series of medicinal product for the verification procedure remains the same as in the SWM [7].

The choice of methodology for analysis. This article does not discuss the cases where an API quality control is proposed for a new analysis technique, and it is necessary to describe the development process and complete validation.

Methods of quantitative determination in the monograph on finished drugs occur several times - in the case of a dissolution test for solid dosage forms, to determine the homogeneity of the content and the quantitative content of the API.

When developing the SPhU monograph on finished drugs, several approaches are used - based on the techniques presented in the monographs on the API, using monographs of leading pharmacopoeias or developing new approaches. For example, one of the risks involved in the transfer of pharmacopoeial spectrophotometric methods of quantitative determination of API in a substance on a finished medicinal product is the change in the concentration of the active substance and the influence of auxiliary substances and / or concentrates on the specificity of the procedure. When choosing existing pharmacopoeial methods for analyzing API in finished drugs, there are risks with the choice of pharmacopoeia. For example, the European Pharmacopoeia does not contain monographs on finished drugs, therefore, they often choose quality control methods that are recommended by USP or BP or other pharmacopoeias. In turn, when choosing techniques for spectrophotometric quantitative determination of API in finished drugs, it is advisable to use those based on the use of standard samples that increase the specificity of the method, that is, the advantage should be given to the monographs of the USP, the Japanese Pharmacopoeia, etc.

New approaches include developing methods for quality control of finished drug products. Methods of quality control of products are developed most often by the manufacturers of finished drugs, based on the features of equipment and technological process used in the manufacture, equipment of factory and workshop laboratories.

The choice of a pharmacopoeial method for quantitative determination of API in finished drug products provides for the application of the same criteria for evaluating the acceptability of the results as for validation, but somewhat to a lesser extent. According to the US Pharmacopoeia, it is expedient to verify only the characteristics of a specific test method [6, 14] (Fig. 1) during verification.

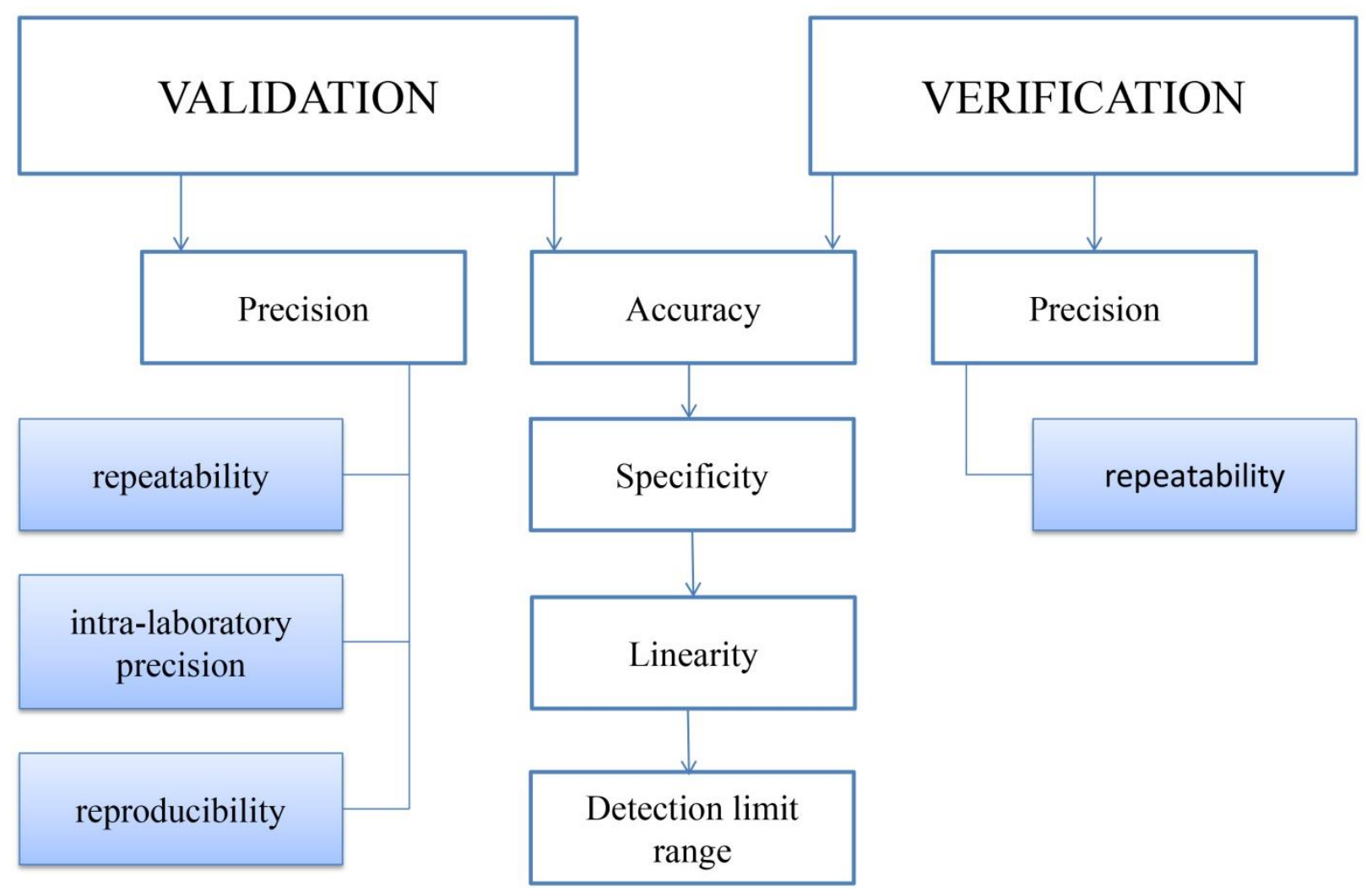

Fig. 1. Comparison of validation characteristics of quantitative determination methods during validation and verification $[14,15]$ 
Verification work should be consistently conducted at different levels and at different stages of the drug's lifecycle using a combination of different validation characteristics such as specificity, linearity, accuracy, precision and detection limit [7,8]. All this is due to the fact that the adaptation of the proposed methodology may not be the best option in the case where the medicines contain the same API, but other components (depending on the manufacturer) [4].

The next step in performing the verification procedure after selecting the method of analysis is to calculate the complete uncertainty of the analysis results $\left(\Delta_{A s}\right)$, expressed as a one-way confidence interval for a probability of $95 \%$, based on the tolerances of the active ingredient content in the finished drugs in accordance with the requirements of the State Pharmacopoeia of Ukraine [6, 7], which is compared with the maximum permissible uncertainty of the analysis $\left(\max \Delta_{A s}\right)$. The prediction of complete uncertainty in the results of the analysis is necessary to confirm the correctness of the technique during reproduction in another laboratory [10] and, according to the requirements of the first edition of SPhU [16], depended on the uncertainty of the sample preparation $\left(\Delta_{S p}\right)$ and the uncertainty of the final analytical operation $\left(\Delta_{F A O}\right)$. According to the recommendations of the second edition of SPHU, the uncertainty of standard attestation $\left(\Delta_{R S}\right)$, which is usually very small and can be neglected, is added to the total uncertainty of the analysis [10].

Consider this procedure on the example of finished drugs in the form of tablets. In the first edition of SPhU in the general article "Tablets", deviations in the content of the active ingredient in finished drugs were shown depending on the dosage used to calculate the critical values for the parameters of linearity, precision and correctness for quantitative determination $[12,13]$.

To calculate the utility criteria of the methodology in accordance with the requirements of the 2 nd edition of the SPhU for the validated production technology of the finished dosage formulation, when the values of the content of the active substance in percentages to the nominal content are known $\left(X_{0}\right)$ and the standard deviation of content heterogeneity $\left(R S D_{\text {unif }}\right)$ are known, for obtaining the limit values of tolerances the content of the ingredient it is expedient to use the general ratio [10]:

$$
\begin{aligned}
& X_{0}-0.37 R S D_{\text {unif }}-\max \Delta_{A s} \leq X \leq X_{0^{+}} \\
& +0.37 R S D_{\text {unif }}+\max \Delta_{A s} .
\end{aligned}
$$

This ratio is obtained by using the weight (close to the weight of one tablet) of the powder $n$ tablets with recalculation to the average weight of the tablet:

$$
X_{0}-\frac{\Delta_{\text {unif }}}{\sqrt{n}}-\max \Delta_{A s} \leq X \leq X_{0}+\frac{\Delta_{\text {unif }}}{\sqrt{n}}+\max \Delta_{A s} .
$$

Typically, a powder obtained from 20 units of a solid dosage form $(\mathrm{n}=20)$ is used for quantitative determination. Then for probability $P_{l}=95 \%$ obtain:

$$
\frac{\Delta_{\text {unif }}}{\sqrt{20}}=\frac{1.65 \cdot R S D_{\text {unif }}}{\sqrt{20}}=0.37 \cdot R S D_{\text {unif }} .
$$

The resulting content tolerances are used to calculate the maximum permissible uncertainty of the results of the analysis $\left(\max \Delta_{A s}\right)$, which corresponds to the inequation:

$$
\max \Delta_{A s} \leq 0.32 B,
$$

where $B$ - the half-width of the regulated concentration limits.

In the case of carrying out quantitative determination methods, when performing tests such as Uniformity of dosage units» and «Dissolution for solid dosage forms», $\max \Delta_{A s}$ is always equal to $3.0 \%$ [8].

According to the requirements of SWM [7], the total uncertainty of the results of the analysis $\Delta_{A s}$, which consists of the uncertainty of the sample preparation $\left(\Delta_{S p}\right)$ and the uncertainty of the final analytical operation $\left(\Delta_{F A O}\right)$, is calculated:

$$
\Delta_{A s} \leq \sqrt{\Delta_{F A O}^{2}+\Delta_{S p}^{2}} .
$$

In turn, the predicted uncertainty of sample preparation should be insignificant in comparison with the permissible uncertainty of the analysis results $\left(\Delta_{A s}\right)$ :

$$
\Delta_{S p} \leq \Delta_{A s} \cdot 0.32
$$

The predicted uncertainty of sample preparation is found using the requirements for the maximum acceptable uncertainty of the volumetric glass wares and weights depending on the methodology of the analysis. It is known that in the spectrophotometry method in the standard version, as a rule, sample preparation affects the complete uncertainty of the analysis. To reduce the influence of sample preparation on the predicted uncertainty of the spectrophotometric analysis, nominal weights are used and the volume of dilutions is increased [8].

When the effect of sample preparation is significant, in order to confirm the correctness of the technique when reproduced in another laboratory, a forecast of complete uncertainty of the method is required. For this purpose, the forecast of uncertainty of the final analytical operation $\left(\Delta_{F A O}\right)$, which depends on the methodology used.

For spectrophotometric techniques $\Delta_{F A O}$, according to SWM [6], were calculated taking into account the spectrophotometric uncertainty of optical density $\left(\mathrm{s}_{\mathrm{r}}\right)$, which is $0.52 \%$ by the formula:

$$
\Delta_{F A O}=1.65 \cdot \sqrt{\frac{2 \cdot s_{r}^{2}}{3}} .
$$

In calculating the uncertainty of the final analytical operation for spectrophotometric techniques, the 2nd edition of the $\mathrm{SPhU}$ proposes spectrophotometric uncertainty of the optical density to be $0.2 \%$ (according to the instrument passport) and take into account the experi- 
mentally found cuvette uncertainty $\left(s_{\text {cell, }, r}\right)$ of $0.1 \%$ using the equation [10]:

$$
\Delta_{F A O}=1.65 \cdot \sqrt{\frac{2 \cdot\left(s_{r}^{2}+s_{c e l l, r}^{2}\right)}{3}} .
$$

The predicted total uncertainty of the results of the analysis should not exceed the maximum permissible uncertainty of the results of the analysis $\left(\Delta_{A s} \leq \max \Delta_{A s}\right)$.

Verification of the specificity of the verified method for quantifying the API in finished drugs is practically the same as the procedure provided by the SWM [7]. A necessary condition for the specificity remains to demonstrate the effect of placebo (other active ingredients and excipients) on the results of the analysis. The specificity of the analytical technique is proven, if neither the solvent, nor the reagents nor the components of placebo do not worsen the results of the procedure. In cases where the placebo components influence the results of the procedure, a more detailed assessment of specificity may be required to demonstrate the suitability of the technique for a particular drug.

For a nonspecific spectrophotometric technique, the specificity depends on the substantiated proven lack of influence on the optical absorption of APIs of other components of the drug (background absorption), of the decomposition products $A_{\text {blank }}$. And thus, the obtained relative systematic error $\left(\delta_{\text {noise }}\right)$ should not exceed the maximum allowable systematic error $(\max \delta)[7,11]$ :

$$
\frac{A_{\text {blank }}}{A_{s t}} \cdot 100 \leq \max \delta \% \text {. }
$$

Thus, determined in the study of specificity, the systematic error should not exceed the maximum permissible systematic error:

$$
\delta \leq \max \delta \% .
$$

The range of application of the technique depends on its purpose and is determined by studying the linearity. Linearity, accuracy and precision of quantitative determination methods are studied at 9 concentrations of the model solution, which depends on the analysis method and cover the range from $80 \%$ to $120 \%$ (step 5) of the nominal selected concentration in determining the quantitative content of API from $55 \%$ to $135 \%$ (step 10) - when determining the amount of active substance that passes into the dissolution medium during the pharmaco-technological test "Dissolution for solid dosage forms", from $70 \%$ to $130 \%$ (step 10) - when determining the homogeneity of API content in the dosage form [8].

Under the term "model solution" takes a solution prepared in the laboratory and contains all active and auxiliary substances with precision weights of ingredients corresponding to the dosage form according to the manufacturer's certificate / specification.

The preparation of model solutions is carried out according to the chemical composition calculated according to the equation of the material balance and given in the specification on the medicinal product. The model solution, depending on the physical and chemical properties and the concentration of active and auxiliary substances of the dosage form, can affect the results of linearity. In practice, it has been found that in order to obtain linear dependence, for solid dosage forms containing less than $10 \%$ of the active ingredient from the average mass, it is advisable to use concentrated API solutions for the preparation of model solutions. To the aliquot of the concentrated solution equivalent from $80 \%$ to $120 \%$ of the nominal weight gain in accordance with the analytical method, add all other components of the preparation in the amount corresponding to the prescribed amount.

At the same time, in spectrophotometric trials, when the exposure to placebo $\left(\delta_{\text {exc }}\right)$ in the total background absorption ( $\delta_{\text {noise }}$ ) is insignificant, that is, the relation:

$$
\delta_{e x c} \leq 0.32 \cdot \max \delta=0.32 \cdot 0.32 \cdot \max \Delta_{A s}=0.033 \cdot B
$$

for check of the linearity, correctness and precision model solutions can be prepared without the use of other active and auxiliary substances [16].

All other calculation parameters of the validation characteristics of linearity, correctness and precision do not need to be changed, since SPhU requirements meet the previous criteria [7, 8, 17]. The calculation of linearity is carried out by the least squares method and must be brought in the system of normalized coordinates taking into account the requirements of the SPhU to the free member of the linear dependence (a) and the angular coefficient for the calculated regression line (b):

$$
Y_{i}=b \cdot X_{i}+a
$$

The use of normalized coordinates allows obtaining the eligibility criteria for the correlation coefficient $(r)$ in the form of the ratio:

$$
r \geq r_{\min }
$$

The correctness of the methodology of analysis depends on the statistical and practical insignificance:

$$
\delta \%=|\bar{Z}-100| \leq \Delta_{\bar{Z}}-\frac{\Delta_{A s}}{\sqrt{g}} .
$$

The criterion for the statistical insignificance of the systematic error $(\delta)$ depends on the actual uncertainty of the analysis $\Delta_{A s}$ and should not statistically differ from zero. This requirement is not correct, since the higher the precision of the methodology of analysis, the lower the values of $\delta$ become statistically significant [18].

In practice, the concept of practical insignificance of systematic error is used where the criterion depends only on the content tolerances, but does not depend on the actual uncertainty of the analysis $\Delta_{\mathrm{As}}$ :

$$
\delta \% \leq \max \delta=0.32 \cdot \max \Delta_{A s}=0.1 \cdot B .
$$


Precision is considered as a one-way confidence interval $(\Delta Z)$, which should not exceed the maximum permissible uncertainty of the analysis:

$\Delta_{Z} \leq \Delta_{\text {Asmax }}$
$\Delta_{Z}=S_{Z}(\%) \cdot t(95 \%, n-1)$.

Proceeding from the foregoing, the following procedure for the verification of the methods of quantitative determination of solid dosage finished drugs is proposed (Fig. 2).

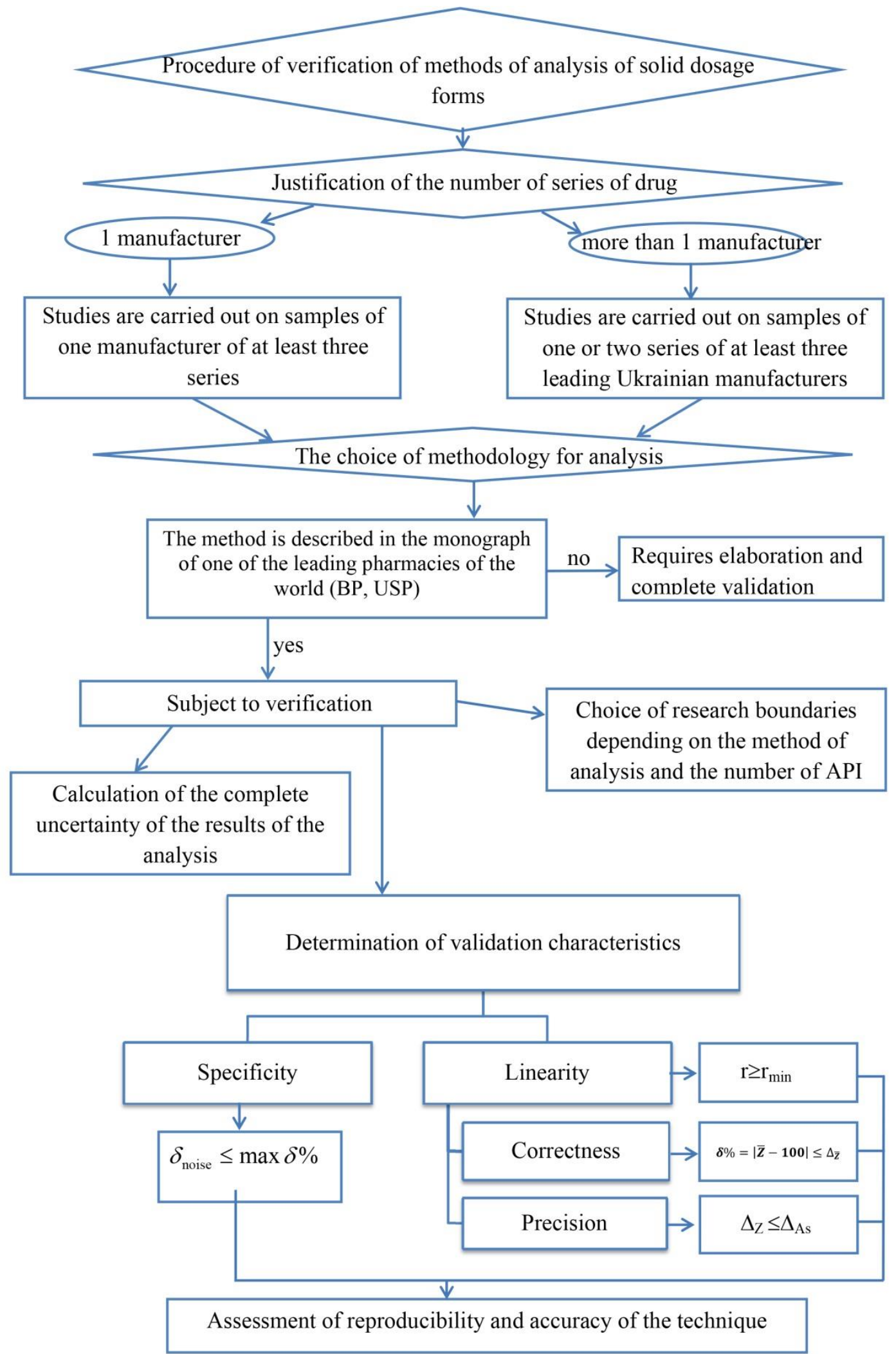

Fig. 2. Procedure for verification of methods for quantitative determination of finished drug products in accordance with the requirements of the 2 nd edition of the State Pharmacopoeia of Ukraine 
7. Conclusions from the conducted research and prospects for further development of this field

1. The standard working method "The procedure for verification of analytical methods in research laboratories", which was proposed for use in the analysis of finished medicinal products, was studied.

2 . The changes to the existing standard working methodology are proposed and the scheme of verifica- tion of the spectrophotometric method of quantitative determination of active pharmaceutical ingredients in tablets is proposed, taking into account the requirements of the second edition of the State Pharmacopoeia of Ukraine to the general monographs "Tablets" and "Statistical analysis of the results of the chemical experiment".

\section{References}

1. Lytvynenko L. L., Sobkova A. O. Perspektyvy rozvytku farmatsevtychnoho rynku Ukrainy v umovakh pohlyblennia protsesiv yevrointehratsii // Problemy pidvyshchennia yevrointehratsii. 2015. Issue 40. P. 51-56.

2. Derzhavna Farmakopeia Ukrainy. Kharkiv: RIREH, Derzhavne pidpryiemstvo «Naukovo-ekspertnyi farmakopeinyi tsentr», 2001. $556 \mathrm{p}$.

3. Rambla-Alegre M., Esteve-Romero J., Carda-Broch S. Is it really necessary to validate an analytical method or not? That is the question // Journal of Chromatography A. 2012. Vol. 1232. P. 101-109. doi: http://doi.org/10.1016/j.chroma.2011.10.050

4. Srivastava R. K., Kumar S. S. An updated review: analytical method validation // European journal of pharmaceutical and medical research. 2017. Vol. 4, Issue 9. P. 774-784.

5. Pharmaceutical Validation-A Review / Reddy B. V., Ujwala P., Sandeep P., Deepthi A. // International Journal of Research in Pharmacy and Life Sciences. 2014. Vol. 2, Issue 2. P. 236-247. 2008. $620 \mathrm{p}$.

6. Derzhavna Farmakopeia Ukrainy. Vol. 2. Kharkiv: Derzhavne pidpryiemstvo «Naukovo-ekspertnyi farmakopeinyi tsentr»,

7. Monografii na gotovye lekarstvennye sredstva Gosudarstvennoi Farmakopei Ukrainy: istoriia i strategiia razrabotki / Tovmasian E. K., Krupa N. A., Matvienko T. N. et. al. // Farmakom. 2012. Issue 1-2. P. 39-45.

8. Derzhavna Farmakopeia Ukrainy. Vol. 1. Kharkiv: Derzhavne pidpryiemstvo «Ukrainskyi naukovyi farmakopeinyi tsentr yakosti likarskykh zasobiv», 2015. $1128 \mathrm{p}$.

9. Peresmotr obshchego teksta 5.3.N.1. Statisticheskii analiz rezultatov khimicheskogo eksperimenta dlia vkliucheniia $\mathrm{v}$ Dopolnenie 2 Gosudarstvennoi Farmakopei Ukrainy 2-go izdaniia / Grizodub A. I., Leontev D. A., Dmitrieva M. V., Volovik N. V. // Farmakom. 2018. Issue 1. P. 9-15.

10. Derzhavna Farmakopeia Ukrainy. Kharkiv: Derzhavne pidpryiemstvo «Ukrainskyi naukovyi farmakopeinyi tsentr yakosti likarskykh zasobiv», 2018. $336 \mathrm{p}$.

11. ISO/IEC Guide 99:2007 International Vocabulary of Metrology - Basic and General Concepts and Associated Terms (VIM). 2007. URL: http://metrology.kiev.ua/files/ISO_IEC_Guide_99_2007.pdf

12. JCGM 200:2008. International Vocabulary of Metrology. - Basic and General Concepts and Associated Terms (VIM). 2008. URL: https://www.bipm.org/utils/common/documents/jcgm/JCGM_200_2008.pdf

13. Analytical Procedures and Methods. Validation for Drugs and Biologics. Pharmaceutical Quality/CMC, 2015. URL: https://goo.gl/3jEAKF

14. USP 41 - NF 36. - The United States Pharmacopeia and National Formulary 2018. United States Pharmacopoeial Convention Inc., 2017. 8200 p.

15. Pro zatverdzhennia Poriadku sertyfikatsii yakosti likarskykh zasobiv dlia mizhnarodnoi torhivli ta pidtverdzhennia dlia aktyvnykh farmatsevtychnykh inhrediientiv, shcho eksportuiutsia: Nakaz MOZ Ukrainy No. 1008. 07.12.2012. URL: https://zakon.rada.gov.ua/laws/show/z2218-12

16. Derzhavna Farmakopeia Ukrainy. Kharkiv: RIREH, Derzhavne pidpryiemstvo «Naukovo-ekspertnyi farmakopeinyi tsentr», 2004. $494 \mathrm{p}$.

17. OMCL Network of the Council of Europe. General document PA/PH/OMCL (13) 82 2R. Validation of analytical procedures. EDQM of the Council of Europe. URL: https://www.edqm.eu/medias/fichiers/validation_of_analytical_procedures_ paphomcl_13_82_2r.pdf

18. Grizodub A. I. Standartizovannye protsedury validatsii metodik kontrolia kachestva lekarstvennykh sredstv. Kharkiv: Gosudarstvennoe predpriiatie «Ukrainskii nauchnii farmakopeinii tsentr kachestva lekarstvennykh sredstv», 2016. 396 p.

Received date 21.04.2019

Accepted date 23.05.2019

Published date 28.06.2019

Nataliia Bevz, PhD, Associate Professor, Department of Pharmaceutical Chemistry, National University of Pharmacy, Pushkinska str., 53, Kharkiv, Ukraine, 61002

E-mail: natali.bevz.60@gmail.com

Victoria Georgiyants, Doctor of Pharmacy, Professor, Head of Department, Department of Pharmaceutical Chemistry, National University of Pharmacy, Pushkinska str., 53, Kharkiv, Ukraine, 61002

E-mail: vgeor@ukr.net

Oleksandr Gryzodub, Doctor of Chemical Sciences, Professor, Director, Ukrainian Scientific Pharmacopoeial Centre for Quality of Medicines, Astronomichna str., 33, Kharkiv, Ukraine, 61085

E-mail: gryzodub@phukr.kharkov.ua 